\title{
Biogeographic variations of picophytoplankton in three contrasting seas: the Bay of Bengal, South China Sea and Western Pacific Ocean
}

\author{
Yuqiu Wei ${ }^{1}$, Danyue Huang ${ }^{1}$, Guicheng Zhang ${ }^{2,3}$, Yuying Zhao ${ }^{2,3}$, Jun Sun ${ }^{2,3, *}$ \\ ${ }^{1}$ Institute of Marine Science and Technology, Shandong University, 72 Binhai Road, Qingdao 266200, PR China \\ ${ }^{2}$ Research Centre for Indian Ocean Ecosystem, Tianjin University of Science and Technology, Tianjin 300457, PR China \\ ${ }^{3}$ Tianjin Key Laboratory of Marine Resources and Chemistry, Tianjin University of Science and Technology, Tianjin 300457, PR China
}

\begin{abstract}
Marine picophytoplankton are abundant in many oligotrophic oceans, but the known geographical patterns of picophytoplankton are primarily based on small-scale cruises or timeseries observations. Here, we conducted a wider survey (5 cruises) in the Bay of Bengal (BOB), South China Sea (SCS) and Western Pacific Ocean (WPO) to better understand the biogeographic variations of picophytoplankton. Prochlorococcus (Pro) were the most abundant picophytoplankton (averaging [1.9-3.6] $\times 10^{4} \mathrm{cells} \mathrm{ml}^{-1}$ ) across the 3 seas, while average abundances of Synechococcus (Syn) and picoeukaryotes (PEuks) were generally 1-2 orders of magnitude lower than Pro. Average abundances of total picophytoplankton were similar between the BOB and SCS $\left(4.7 \times 10^{4} \mathrm{cells} \mathrm{ml}^{-1}\right)$, but were close to 2-fold less abundant in the WPO $\left(2.5 \times 10^{4} \mathrm{cells} \mathrm{ml}^{-1}\right)$. Pro and Syn accounted for a substantial fraction of total picophytoplankton biomass (70-83\%) in the 3 contrasting seas, indicating the ecological importance of Pro and Syn as primary producers. Pro were generally abundant in oligotrophic open waters; however, the exceptional presence of Pro near the SCS coast was potentially associated with the Kuroshio intrusion. Syn and PEuk abundances were higher near freshwater-dominated areas, which was likely due to dilution waters. Water temperature and cold eddies were also major drivers responsible for the biogeographic distributions of picophytoplankton. Although Pro, Syn and PEuks showed negative correlations with nutrient concentrations, their maximal abundances in vertical distribution showed positive correlations with the nutricline depth, indicating that nutrient availability plays a 2 -faceted role in regulating the biogeographic variation in picophytoplankton.
\end{abstract}

KEY WORDS: Picophytoplankton · Abundance - Biogeographic variation - Bay of Bengal · South China Sea $\cdot$ Western Pacific Ocean

\section{INTRODUCTION}

Marine picophytoplankton refer to a genetically diverse group of photosynthetic organisms, which include picocyanobacteria of the genera Prochlorococcus (Pro) and Synechococcus (Syn), as well as a diverse assemblage of picoeukaryotes (PEuks). Pro and Syn are both ecologically dominant and widespread members in warm oligotrophic waters (Liu et al. 2007, Seymour et al. 2010), although Pro are gen-

${ }^{*}$ Corresponding author: phytoplankton@163.com erally more abundant than Syn and PEuks, often by 10 -fold or more in the open ocean (Jiao \& Yang 2002, Flombaum et al. 2013). Furthermore, Syn and PEuks have a wide geographical distribution that covers both oligo- and mesotrophic oceanic and coastal areas from pole to pole (Olson et al. 1990, Flombaum et al. 2013, Grébert et al. 2018). Observations in the oligotrophic Pacific Ocean and Atlantic Ocean have revealed that picophytoplankton can account for approximately $60-80 \%$ of the total primary produc-

(1) The authors 2020. Open Access under Creative Commons by Attribution Licence. Use, distribution and reproduction are unrestricted. Authors and original publication must be credited. 
tivity (Campbell et al. 1997, Grob et al. 2011). In eutrophic coastal waters, picophytoplankton also play a significant role with their high abundance and carbon biomass, contributing nearly $42-55 \%$ of the total primary productivity (Gaulke et al. 2010), and are therefore thought to contribute roughly $1 / 3$ to global net primary production (Quere et al. 2005). Given their ubiquitous distribution and high abundance, as well as their significant contribution to global net primary production, picophytoplankton have been considered to have substantial impacts on oceanic ecosystems and global biogeochemical cycles (Flombaum et al. 2013). Presenting the biogeographic variations of picophytoplankton in different ecosystems is thus central to our understanding of where and how these particular phytoplankton contribute to the biogeochemical cycles.

A large data set has been accumulated on picophytoplankton populations in the world oceans (e.g. Campbell et al. 1997, Zhang et al. 2013, Chen et al. 2015, Wei et al. 2019b), but a caveat to their investigation is that the abundances and distributions of different picophytoplankton populations were measured from just 1 oceanic or coastal ecosystem, i.e. previous estimates could not address large-scale spatial variations in picophytoplankton populations. Accordingly, our limited understanding of largescale biogeographic variations in picophytoplankton constrains our ability to incorporate them into marine biogeochemical models (Flombaum et al. 2013). As a part of the warm pool covering the tropical eastern Indian Ocean (EIO) and West Pacific Ocean (WPO) (Sengupta \& Ravichandran 2001), the Bay of Bengal (BOB) has received far less attention in research on picophytoplankton than the South China Sea (SCS) and WPO. The SCS, as a crossroads of the EIO and WPO, is profoundly influenced by neighboring physical processes, such as circulations and water masses.
However, the 3 seas still have contrasting differences in structural and functional components $(\mathrm{Qu}$ et al. 2005, Cheung et al. 2008, Wei et al. 2019b). Importantly, the variability in picophytoplankton abundance and distribution is intimately related to these physical processes, as well as environmental factors (e.g. temperature, salinity, irradiance and nutrient availability) (Landry et al. 2003, Lee et al. 2014, Grébert et al. 2018). Nevertheless, to date, there is a lack of comprehensive knowledge on the abundances and distributions of picophytoplankton throughout the BOB, SCS and WPO. In that context, the BOB, SCS and WPO appear to be ideal fields for ecological surveys on biogeographic variations in picophytoplankton.

Here, we report on abundances and distributions of 3 picophytoplankton groups using flow cytometric (FCM) analyses in 3 contrasting seas: BOB, SCS and WPO. The purpose of this paper is to develop a more comprehensive picture of large-scale variability of picophytoplankton in these 3 complicated ecosystems. The abundance datasets were compiled to analyze the associated environmental variables, and the possible mechanisms shaping picophytoplankton variations in the 3 contrasting seas are also discussed.

\section{MATERIALS AND METHODS}

\subsection{Field surveys}

Sampling occurred on 5 cruises of opportunity aboard the RVs 'Shiyan I,' 'Dongfanghong 2' and 'Kexue 3 ' in the BOB, SCS and WPO (Fig. 1). We joined 3 SCS cruises including the northeastern SCS (referred to as NSCS; 7 July to 10 August 2017), the central SCS (CSCS; 12 May to 13 June 2017) and the western SCS (WSCS; 3 September to 13 October

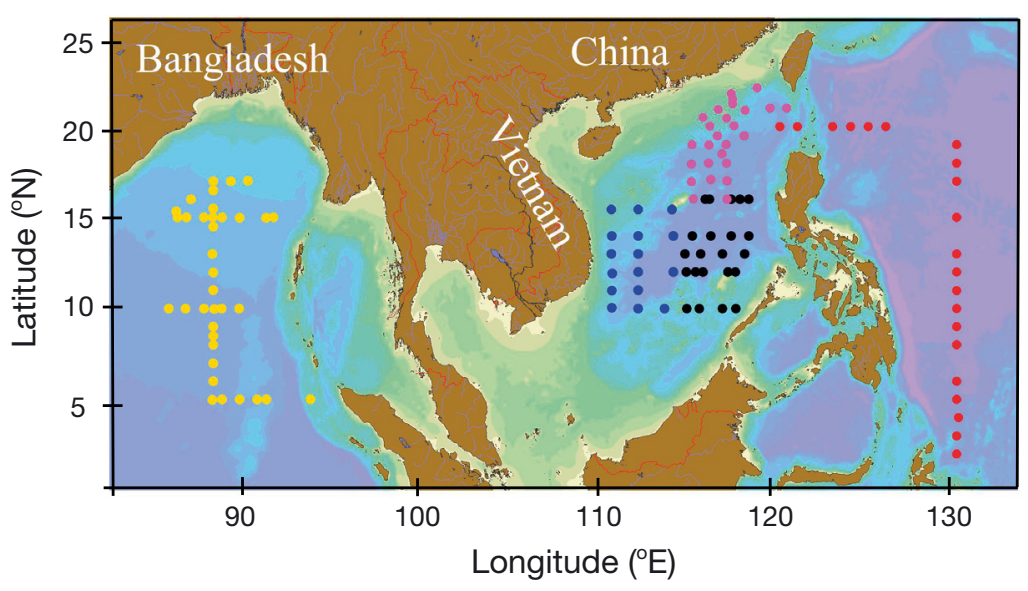

2016 WPO

- 2017 NSCS

- 2017 CSCS

- 2016 WSCS - 2016 BOB
Fig. 1. Stations sampled in 2016 (WPO: Western Pacific Ocean, WSCS: western South China Sea, BOB: Bay of Bengal) and 2017 (NSCS: northern South China Sea, CSCS: central South China Sea). Different colors denote different sampling cruises 
2016). These 3 cruises sampled 80 stations covering the entire SCS and its continental shelf area. The WPO cruise $\left(3-20^{\circ} \mathrm{N}, 125-130^{\circ} \mathrm{E}\right)$ was conducted aboard the RV 'Kexue 3' from 27 September to 25 October 2016, and 21 stations were investigated. Another cruise of opportunity aboard the RV 'Dongfanghong 2 ' (8 October to 20 December 2016) sampled 36 stations in the $\mathrm{BOB}\left(5-20^{\circ} \mathrm{N}, 85-95^{\circ} \mathrm{E}\right)$, within the eastern Indian Ocean. A variety of oceanographic conditions and habitats were sampled between $3^{\circ}$ and $23^{\circ} \mathrm{N}$ latitude.

\subsection{Sampling and analysis}

Seawater samples and measurements of temperature and salinity were performed using a SeaBird conductivity/temperature/depth (CTD) meter (SBE 19 Plus) equipped with 10 or 121 Niskin bottles. FCM samples $(2 \mathrm{ml}$ ) for picophytoplankton were generally collected from 7 depths at most stations, including surface $(5 \mathrm{~m}), 25,50,75,100,150$ and $200 \mathrm{~m}$. At some stations in the SCS, however, picophytoplankton samples were collected from 10 depths $(5,10,20,25$, $50,65,75,100,150,200 \mathrm{~m}$ ). Seawater samples for picophytoplankton were fixed and preserved on board following the standard methods detailed by Jiao \& Yang (2002) and Jiao et al. (2005). A total of 2658 samples were collected in the BOB, SCS and WPO. Ancillary nutrient samples $(300 \mathrm{ml})$ were filtered through $0.45 \mu \mathrm{m}$ cellulose acetate membrane filters, and then quickly frozen at $-20^{\circ} \mathrm{C}$ and analyzed as soon as possible. Nutrients, mainly including dissolved inorganic nitrogen (DIN; the sum of the concentrations of nitrate, nitrite and ammonia), dissolved inorganic phosphorus (DIP) and dissolved inorganic silicate (DSi), were determined using a Technicon AA3 Auto-Analyzer (Bran+Luebbe) according to the method reported by Brzezinski \& Nelson (1986) and Karl \& Tien (1992). In addition, we imposed a minimum nutrient concentration of $0.01 \mu \mathrm{mol} \mathrm{l^{-1 }}$ to avoid issues with detection limits.

\subsection{Flow cytometry analysis}

A total volume of only $198 \mu \mathrm{l}$ (flow rate at $66 \mu \mathrm{l}$ $\mathrm{min}^{-1}$ running for $3 \mathrm{~min}$ ) was analyzed using an FCM (BD Accuri C6) equipped with 488 and $640 \mathrm{~nm}$ laser beams. Approximately 10000-40000 events were detected on the FCM. Pro were generally the smallest picophytoplankton cells $(\sim 0.6 \mu \mathrm{m})$ with low chlorophyll a $(\mathrm{chl}$ a) concentrations (Campbell et al.
1997, Liu et al. 2007), showing relatively low red fluorescence signals (FL3, >670 nm). Large PEuks $(1-2 \mu \mathrm{m})$ showed the highest red fluorescence because they were mostly comprised of larger and richer chl a cells (Lee et al. 2014). Pro were discriminated from PEuks based on their lower FL3 and side scatter (SSC) signals, whereas Syn were identified by the orange fluorescence signals (FL2, $585 \pm$ $42 \mathrm{~nm}$ ) because of their characteristic contents of phycoerythrin (Bertilsson et al. 2003, Jiao et al. 2005). Within the present study, Syn, Pro and PEuks were differentiated by their fluorescence signals and scatter properties in the scatterplots of FL2 vs. FL3 and SSC vs. FL3. Yellow-green fluorescent beads $(2 \mu \mathrm{m}$; Polysciences) were added as an internal standard (Calvo-Díaz \& Morán 2006).

A recently published study revealed that the BD Accuri FCM is not an ideal flow cytometer to detect the picophytoplankton populations, and suggested that Pro in the well-lit layers of the water column may be underestimated with the BD Accuri FCM because of the low contents of photosynthetic pigments in cells and only partial resolution from the background noise (Ribeiro et al. 2016). To avoid loss of dispersion and resolution of target cells in the scatterplot due to the overlapping signals with noise, the trigger threshold (600) was set well below the lowest scatter signals from surface Pro cells. Scatter-to-fluorescence crosstalk and spurious scatter events were minimized by setting the polarization of the excitation laser perpendicular to the axis of flow. After these settings, $2 \mathrm{ml}$ of DI (deionized) water were preferentially run at a steady flow rate of $66 \mu \mathrm{min}^{-1}$ to collect and gate the scatter and fluorescence signals of noise. If higher background counts were recorded, the FCM was thoroughly cleaned with $5 \%$ bleach, and rinsed until the background counts fell below 8 events $\mu^{-1}$. The fluorescence and scatter signals were captured with user-built detector assemblies with an extended range by combining the signals from 2 photomultipliers that operate at different gains. The relative gain settings were calibrated by a regression analysis of the events that fall within the linear window of both detectors (van den Engh et al. 2017). This approach allowed simultaneous detection of all picophytoplankton populations ranging from dim surfacedwelling Pro to bright PEuks.

The carbon biomass of Pro, Syn and PEuks in the 3 contrasting seas were calculated based on abundance-to-carbon conversion factors from the literature (Table 1). The conversion factor of PEuks previously used in the WPO was 1500-2100 $\mathrm{fg} \mathrm{C}^{\mathrm{C}} \mathrm{cell}^{-1}$ (Campbell et al. 1997). In the present study, however, 
Table 1. Carbon conversion factors (fg $\mathrm{C} \mathrm{cell}^{-1}$ ) for 3 picophytoplankton populations in 3 contrasting seas. Syn: Synechococcus; Pro: Prochlorococcus; PEuks: picoeukaryotes

\begin{tabular}{|lcccc|}
\hline Study area & Pro & Syn & PEuks & Reference \\
\hline West Pacific Ocean & 53 & 250 & 964 & Campbell et al. (1997) \\
South China Sea & 43 & 112 & 293 & Liu et al. (2007) \\
Bay of Bengal & 32 & 129 & 160 & Wei et al. (2019a) \\
\hline
\end{tabular}

an average conversion factor of $964 \mathrm{fg} \mathrm{C}^{\mathrm{C}} \mathrm{cell}^{-1}$ for PEuks was derived from our estimated PEuks cell sizes according to the empirical relationship (MendenDeuer \& Lessard 2000): $\log C=0.94 \times \log V-0.60$. Thus, this conversion factor may provide a lower estimation of carbon biomass for PEuks than previous biomass values in the WPO.

\subsection{Statistical analysis}

All mean data are given $\pm \mathrm{SD}$. To assess the relative significance of environmental variables in influencing picophytoplankton abundance across the 3 contrasting seas, canonical correspondence analysis (CCA) and Pearson's correlation coefficients were used to explore the relationship between the abundances of 3 picophytoplankton groups and environmental factors. The CCA was performed using Canoco 4.5 software, and Pearson's correlation analysis was achieved using SPSS 25.0 (IBM). Furthermore, graphs were generated by Origin Pro 8.5 and Ocean Data View 4.0. In all tests, statistical significance was accepted at $\mathrm{p}<0.05$. Picophytoplankton abundance was $\log _{10}$-transformed to improve the normality for statistical analysis. Unless otherwise stated, picophytoplankton abundance and biomass used for presenting the spatial distribution are expressed as the depth-weighted averages (calculated by dividing the trapezoidal integration of measured values for each variable by the maximum sampling depth) because Pro and PEuks abundances were relatively low in the surface layer (see Section 3). These depth-weighted averages, which involve a series of abundance variations with depth, were better suited for our distributional patterns than discrete sample data, and were calculated as per Crosbie \& Furnas (2001):

$$
A=\left[\sum_{n}^{n+1} \frac{\left(A_{i}+A_{i+1}\right)}{2} \times\left(D_{i+1}-D_{i}\right)\right] /\left(D_{\mathrm{MSL}}-D_{\mathrm{S}}\right)
$$

where $A_{i}$ is the picophytoplankton abundance (cells $\mathrm{ml}^{-1}$ ) or biomass $\left(\mu \mathrm{g} \mathrm{Cl} \mathrm{l}^{-1}\right.$ ) in sampling layer $i ; n$ is the number of sampling layers, and $D_{i}$ is the depth of sampling layer $i(\mathrm{~m}) ; D_{\mathrm{MSL}}$ and $D_{\mathrm{S}}$ are the depth of the maximum sampling layer $(\mathrm{m})$ and the surface sampling depth $(5 \mathrm{~m})$, respectively.

\section{RESULTS}

\subsection{Hydrography and nutrients}

A surface warm tongue $\left(>30^{\circ} \mathrm{C}\right)$ with salinity $>34$ was observed from 10 to $20^{\circ} \mathrm{N}$ in the WPO (Fig. 2), thereby indicating an apparent influence of the Kuroshio. The high surface temperature and salinity were analogously found in the NSCS, attributable to the fact that the Kuroshio intrusion brought higher salinity and warmer seawater, profoundly changing its water layer structure. By contrast, the SCS and BOB were characterized by low temperature and salinity (Table 2). In the SCS, surface temperature
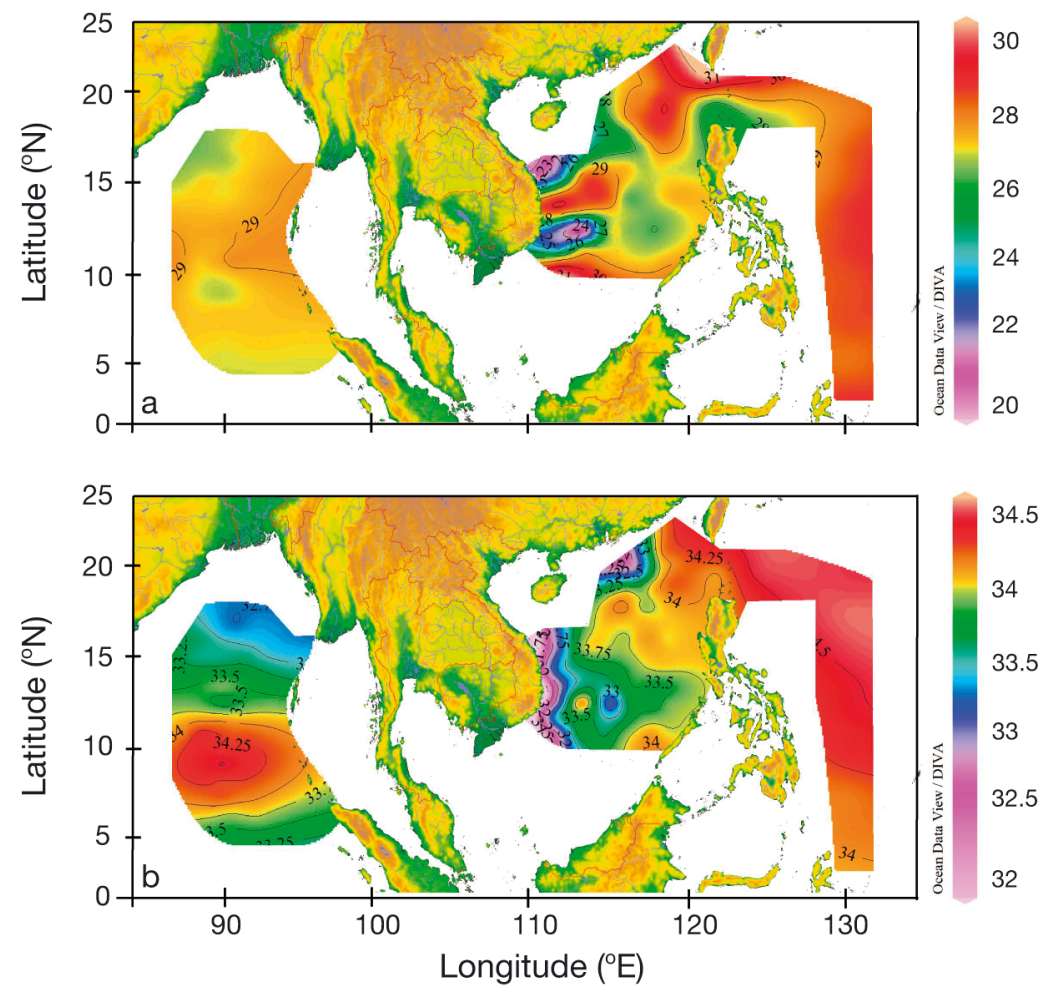

Fig. 2. Spatial variation in surface (a) temperature $\left({ }^{\circ} \mathrm{C}\right.$ ) and (b) salinity in 3 contrasting seas 
Table 2. Mean $\pm \mathrm{SD}$ of temperature $\left({ }^{\circ} \mathrm{C}\right)$, salinity and nutrients $\left(\mu \mathrm{mol} \mathrm{l}^{-1}\right)$ across 3 contrasting seas. DIN: dissolved inorganic nitrogen; DIP: dissolved inorganic phosphorus; DSi: dissolved inorganic silicate

\begin{tabular}{|cccccc|}
\hline Study area & Temperature & Salinity & DIN & DIP & DSi \\
\hline $\begin{array}{c}\text { West Pacific } \\
\text { Ocean } \\
\begin{array}{c}\text { South China } \\
\text { Sea } \\
\text { Bay of Bengal }\end{array}\end{array}$ & $25.9 \pm 4.5$ & $34.6 \pm 0.4$ & $1.85 \pm 3.32$ & $0.17 \pm 0.05$ & $1.91 \pm 0.27$ \\
\hline
\end{tabular}

and salinity were usually lower in the coastal regions due to freshwater influence, whereas sea surface salinity at some coastal stations was $>34$, indicating the effect of coastal upwelling (Fig. 2). Under the influence of coastal runoff, surface temperature in the northern part of the BOB was below $29^{\circ} \mathrm{C}$, with a comparatively low surface salinity of approximately $32-33$. However, the surface colder seawater $\left(\sim 27^{\circ} \mathrm{C}\right)$ with higher salinity $(>34)$ was particularly observed around $10^{\circ} \mathrm{N}$ in the BOB. Analysis of the satellite altimetry revealed that a negative sea level anomaly was present at this site at the time of the 2016 BOB cruise (AVISO, http://las.aviso.altimetry.fr/). Collectively, the sea level anomaly and the hydrographic conditions at this site were consistent with the presence of a cyclonic eddy (i.e. cold eddy).

Contrasting vertical patterns of nutrient concentrations (DIN, DIP and DSi) from the surface to a maximum of $200 \mathrm{~m}$ were observed in the pooled dataset across the 3 seas (Fig. 3). The average values of nutrient concentrations were highest in the BOB followed by the SCS and WPO (Table 2). Analysis of the nutrient profiles revealed that high nutrient concentrations markedly shoaled in the $\mathrm{BOB}$ compared to the other 2 seas, and the nutricline depth was shallow $(<50 \mathrm{~m})$. In the SCS, nutrient concentrations were relatively low in the upper $50-75 \mathrm{~m}$, but increased rapidly from 75 to $200 \mathrm{~m}$, indicating that the depth of the nutricline typically ranged between 50 and $75 \mathrm{~m}$. Due to the pronounced stratification in the WPO, nutrients were generally depleted within the upper $100 \mathrm{~m}$, with a deep nutricline at $\sim 100 \mathrm{~m}$. As expected, there were contrasting differences in physical and chemical backgrounds among the 3 seas.

\subsection{Picophytoplankton abundance}

Pro were the most abundant picophytoplankton across the 3 contrasting seas (Table 3 ). The maximum Pro abundance $\left(7.7 \times 10^{5}\right.$ cells ml $\left.{ }^{-1}\right)$ was observed in the SCS, and average Pro abundance was also highest in the SCS $\left(3.6 \times 10^{4} \mathrm{cells} \mathrm{ml}^{-1}\right)$, followed by the BOB $\left(3.3 \times 10^{4}\right.$ cells ml $\left.{ }^{-1}\right)$ and WPO $\left(1.9 \times 10^{4}\right.$ cells $\mathrm{ml}^{-1}$ ). Average abundances of Syn and PEuks were generally 1-2 orders of magnitude lower than Pro,

\section{Concentration $\left(\mu \mathrm{mol} \mathrm{l}^{-1}\right)$}

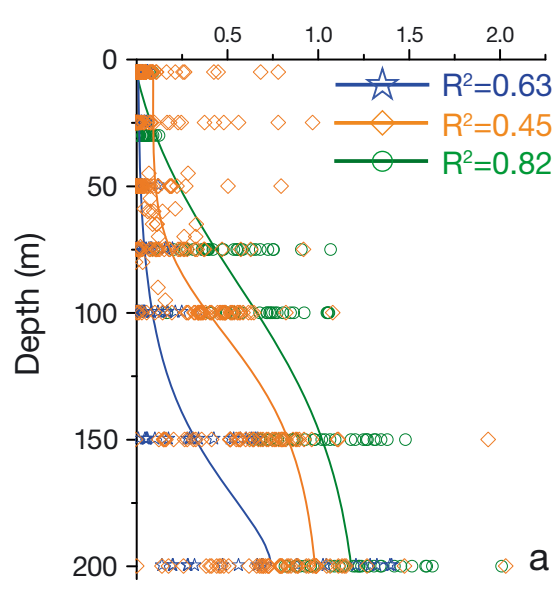

Concentration $(\mu \mathrm{mol} \mathrm{I-1})$

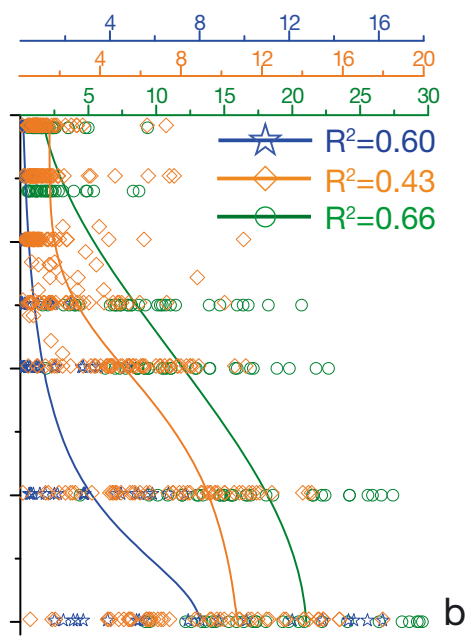

\section{Concentration $\left(\mu \mathrm{mol} \mathrm{I} \mathrm{I}^{-1}\right)$}

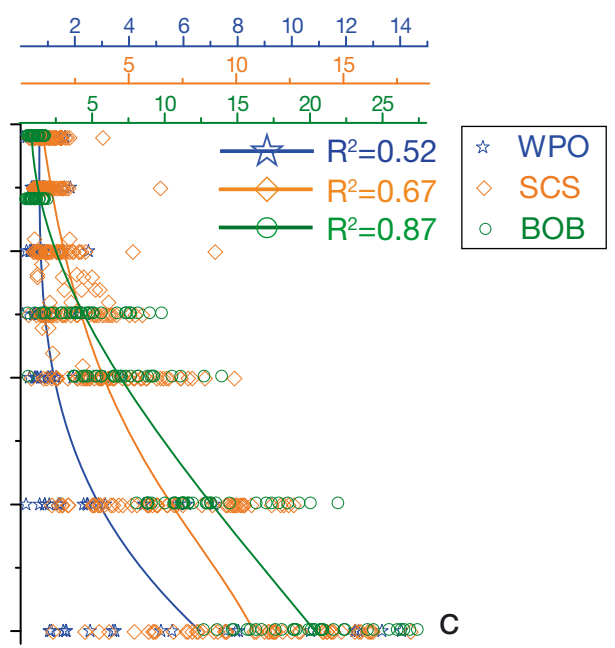

Fig. 3. Vertical profiles for concentrations $\left(\mu \mathrm{mol} \mathrm{l}^{-1}\right.$ ) of (a) dissolved inorganic phosphorus (DIP), (b) dissolved inorganic nitrogen (DIN) and (c) dissolved inorganic silicate (DSi). Symbols and colors represent 3 contrasting seas. Different colored solid lines indicate the curve-fitting trends for all nutrients data $(n=2080)$ versus depth. $\mathrm{R}^{2}$ denotes the fitting variance of the nonlinear regression model. Note the $x$-axis scale in panels $b$ and $c_{i}$ different colored $x$-axes correspond to 3 contrasting seas (WPO: Western Pacific Ocean, SCS: South China Sea, BOB: Bay of Bengal) 
Table 3. Range and mean \pm SD of abundance $\left(\right.$ cells ml $\left.{ }^{-1}\right)$ for 3 groups of picophytoplankton $(\mathrm{n}=2658)$ across 3 contrasting seas. ND: not detected; Syn: Synechococcus; Pro: Prochlorococcus; PEuks: picoeukaryotes

\begin{tabular}{|lcccc|}
\hline & Cell type & West Pacific Ocean & South China Sea & Bay of Bengal \\
\hline Pro & Range & $0.4 \times 10^{3}-1.1 \times 10^{5}$ & $0.4 \times 10^{3}-7.7 \times 10^{5}$ & $0.7 \times 10^{3}-2.0 \times 10^{5}$ \\
& Mean & $(1.9 \pm 0.7) \times 10^{4}$ & $(3.6 \pm 0.4) \times 10^{4}$ & $(3.3 \pm 0.5) \times 10^{4}$ \\
Syn & Range & $0.1 \times 10^{3}-2.9 \times 10^{4}$ & $0.1 \times 10^{3}-1.5 \times 10^{5}$ & $0.2 \times 10^{2}-1.9 \times 10^{5}$ \\
& Mean & $(4.2 \pm 0.9) \times 10^{3}$ & $(8.1 \pm 1.1) \times 10^{3}$ & $(1.1 \pm 0.3) \times 10^{4}$ \\
PEuks & Range & ND $-1.2 \times 10^{4}$ & $\mathrm{ND}-9.2 \times 10^{4}$ & $(3.1 \pm 0.1) \times 10^{3}$ \\
& Mean & $(9.3 \pm 1.7) \times 10^{2}$ & $(2.5 \pm 0.2) \times 10^{3}$ & $1.5 \times 10^{3}-4.2 \times 10^{5}$ \\
Total & Range & $0.7 \times 10^{3}-1.2 \times 10^{5}$ & $0.5 \times 10^{3}-8.2 \times 10^{5}$ & $(4.7 \pm 0.8) \times 10^{4}$ \\
& Mean & $(2.5 \pm 0.4) \times 10^{4}$ & $(4.7 \pm 0.5) \times 10^{4}$ & 1.1 \\
& & & &
\end{tabular}

while average Syn abundance was found as high as $1.1 \times 10^{4}$ cells $\mathrm{ml}^{-1}$ in the BOB. Moreover, the maximum Syn abundance $\left(1.9 \times 10^{5} \mathrm{cells} \mathrm{ml}^{-1}\right)$ was also recorded in the BOB. Overall, the average abundances of the 3 picophytoplankton groups were somewhat similar between the BOB and SCS (Pearson's correlation, $\mathrm{r}=0.98, \mathrm{p}<0.05)$, but were 2 - to 3 fold less abundant in the WPO.

\subsection{Spatial distribution}

The depth-weighted average Pro abundance (referred to as 'Pro abundance') was usually high in oligotrophic open waters (Fig. 4). The maximal Pro abundance was found in the CSCS. Apart from the
CSCS, Pro were exceptionally abundant along the NSCS coast. In the BOB, Pro abundance was relatively high in the northern part and around $10^{\circ} \mathrm{N}$, where the distributional pattern appeared to closely follow the spatial variation in surface currents or water masses. Pro abundance in the WPO, however, was much less abundant than in the SCS and BOB. The depth-weighted average Syn and PEuks abundances (referred to as 'Syn and PEuks abundances') were geographically uneven and varied significantly across the 3 contrasting seas. Syn and PEuks abundances were relatively high in the BOB and SCS, but were low in the WPO. In contrast to Pro, PEuks abundance was broadly higher near the SCS coast, whereas Syn abundance was higher in both coastal and open waters.
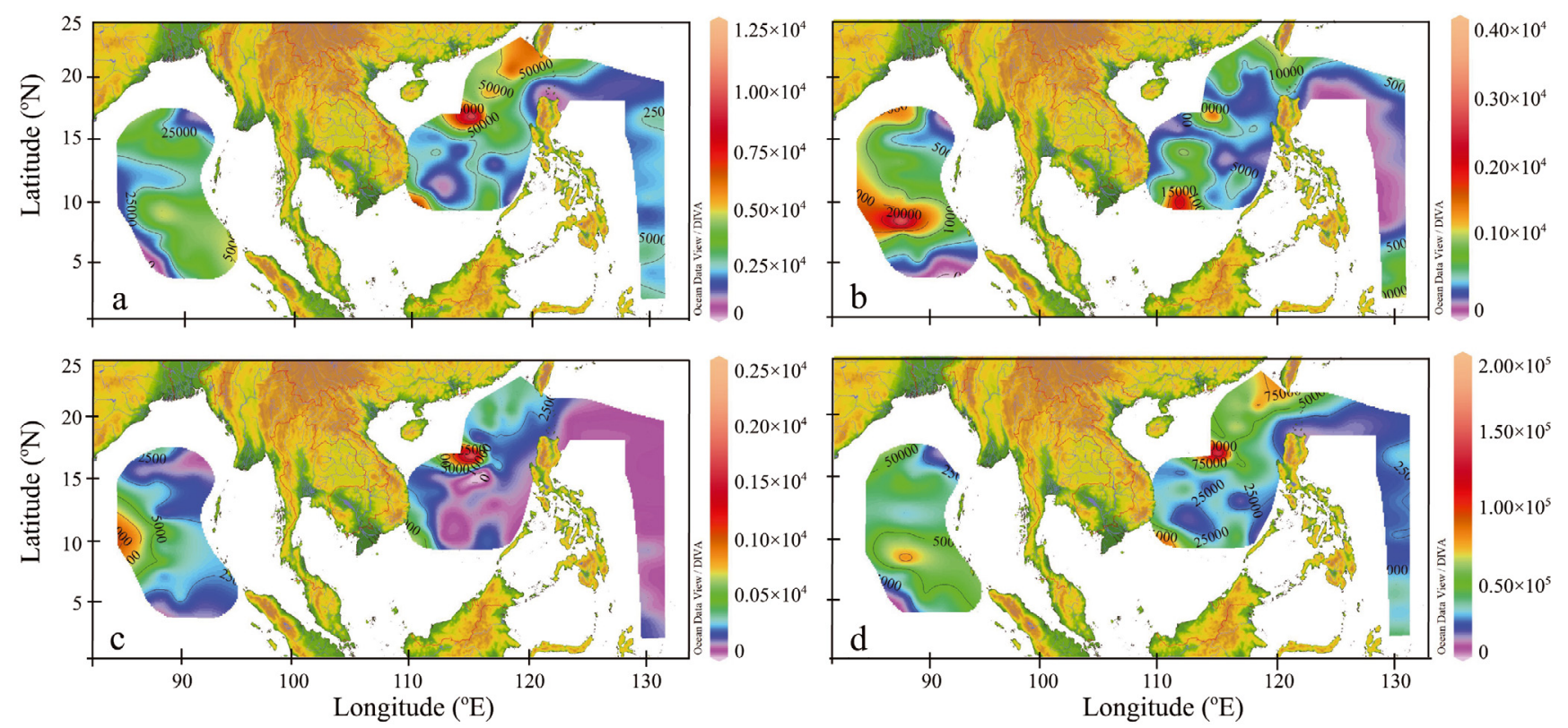

Fig. 4. Spatial distributions for depth-weighted average abundances (cells ml ${ }^{-1}$ ) of (a) Prochlorococcus (Pro), (b) Synechococcus (Syn), (c) picoeukaryotes (PEuks) and (d) total picophytoplankton in 3 contrasting seas. Note the different logarithmic scales on the color bars, reflecting the variability in magnitude of respective picophytoplankton abundances 
All data points of picophytoplankton abundance against depth were analyzed to plot the fitting curves in Fig. 5. There were some similarities in the vertical patterns of the 3 picophytoplankton groups among the BOB, SCS and WPO. Syn were most abundant in surface layer, and only very few cells were counted below $100 \mathrm{~m}$. In the BOB, Syn abundance occurred evenly from the surface to $50 \mathrm{~m}$, and then decreased drastically with depth. In the SCS and WPO, Syn abundance was vertically homogeneous from the surface to depths of about 50-75 and $100 \mathrm{~m}$, respectively. The highest Pro abundance in the BOB was found in the subsurface around $50 \mathrm{~m}$, while in the SCS and WPO, Pro had strong deep maxima at 50-75 and $100 \mathrm{~m}$. PEuks and Pro had similar vertical patterns across the 3 seas, and the peaks of PEuks abundance in the BOB, SCS and WPO were evident at 50, 50-75 and $75 \mathrm{~m}$, respectively. The depths of maximal abundances of Pro, Syn and PEuks were significantly correlated with the nutricline depths in the 3 contrasting seas (Fig. 3; Pearson's correlation, $r=0.87$, $\mathrm{p}<0.01$ ), indicating that the growth of 3 picophytoplankton populations in vertical distribution were possibly controlled by the nutricline.

\subsection{Carbon biomass}

The spatial distributions of depth-weighted average carbon biomass (referred to as 'C biomass') for the 3 picophytoplankton populations were similar to those of abundances (Figs. 4 \& 6; Pearson's correlation, $\mathrm{r}=0.71, \mathrm{p}<0.01)$. This finding indicated that the $\mathrm{C}$ biomass of picophytoplankton appeared to be mainly determined by the abundance rather than the conversion factor (Table 1). The C biomass of total picophytoplankton showed the highest value in the SCS (14.8 $\left.\mu \mathrm{g} \mathrm{Cl}^{-1}\right)$ and the lowest in the BOB $\left(0.9 \mu \mathrm{g} \mathrm{Cl}^{-1}\right)$.

Pro and Syn accounted for a substantial fraction of total picophytoplankton biomass (approximately $70-83 \%$ ) across the 3 seas (Table 4). In contrast, PEuks were not a large component of the total picophytoplankton biomass. The relative biomass of PEuks was low in the BOB (17\%), yet markedly increased by 7 and $13 \%$ in the SCS and WPO, respectively. The spatial variation of average $\mathrm{C}$ biomass for PEuks in the 3 contrasting seas was opposite to that of average abundance (Table 3). This opposite variation may be attributed to the different cellular sizes in PEuks (Table 1). The average $\mathrm{C}$ biomass of total picophytoplankton was highest in the SCS $\left(3.0 \mu \mathrm{g} \mathrm{C}^{-1}\right)$ followed by the WPO (2.9 $\left.\mu \mathrm{g} \mathrm{C}^{-1}\right)$ and BOB $\left(2.6 \mu \mathrm{g} \mathrm{C}^{-1}\right)$.

\subsection{Associated environmental variables governing picophytoplankton biogeography}

CCA and Pearson's correlation analysis were used to identify which key environmental variables explained the biogeographic variations of picophytoplankton in the 3 contrasting seas (Fig. 7, Table 5). CCA is a multivariate statistical analysis of weighted

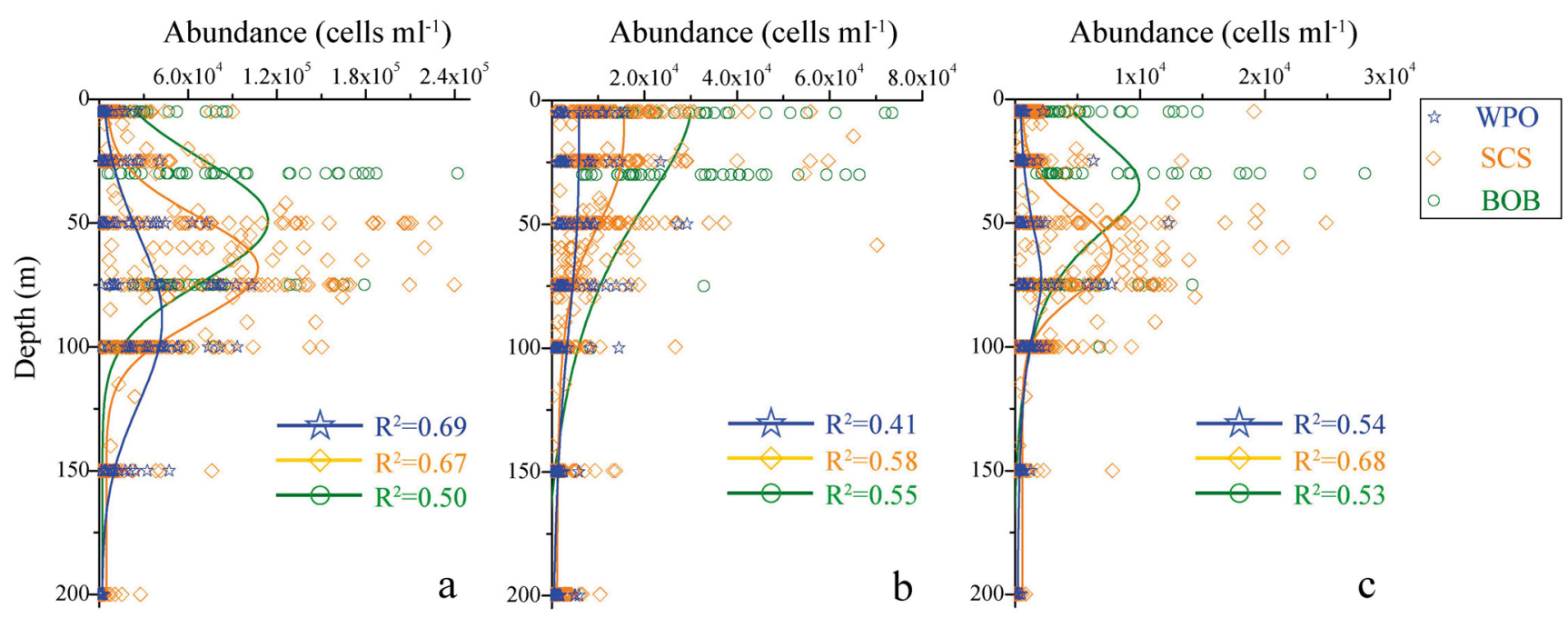

Fig. 5. Vertical profiles for abundances (cells ml-1 ${ }^{-1}$ of (a) Prochlorococcus (Pro), (b) Synechococcus (Syn) and (c) picoeukaryotes (PEuks). Symbols and colors represent 3 contrasting seas (WPO: Western Pacific Ocean, SCS: South China Sea, BOB: Bay of Bengal). Different colored solid lines indicate the curve-fitting trends for all abundance data $(n=2658)$ versus depth. $\mathrm{R}^{2}$ denotes the fitting variance of the nonlinear regression model. Note the different logarithmic scales on the $x$-axes, reflecting variability in the magnitude of the respective picophytoplankton abundances 

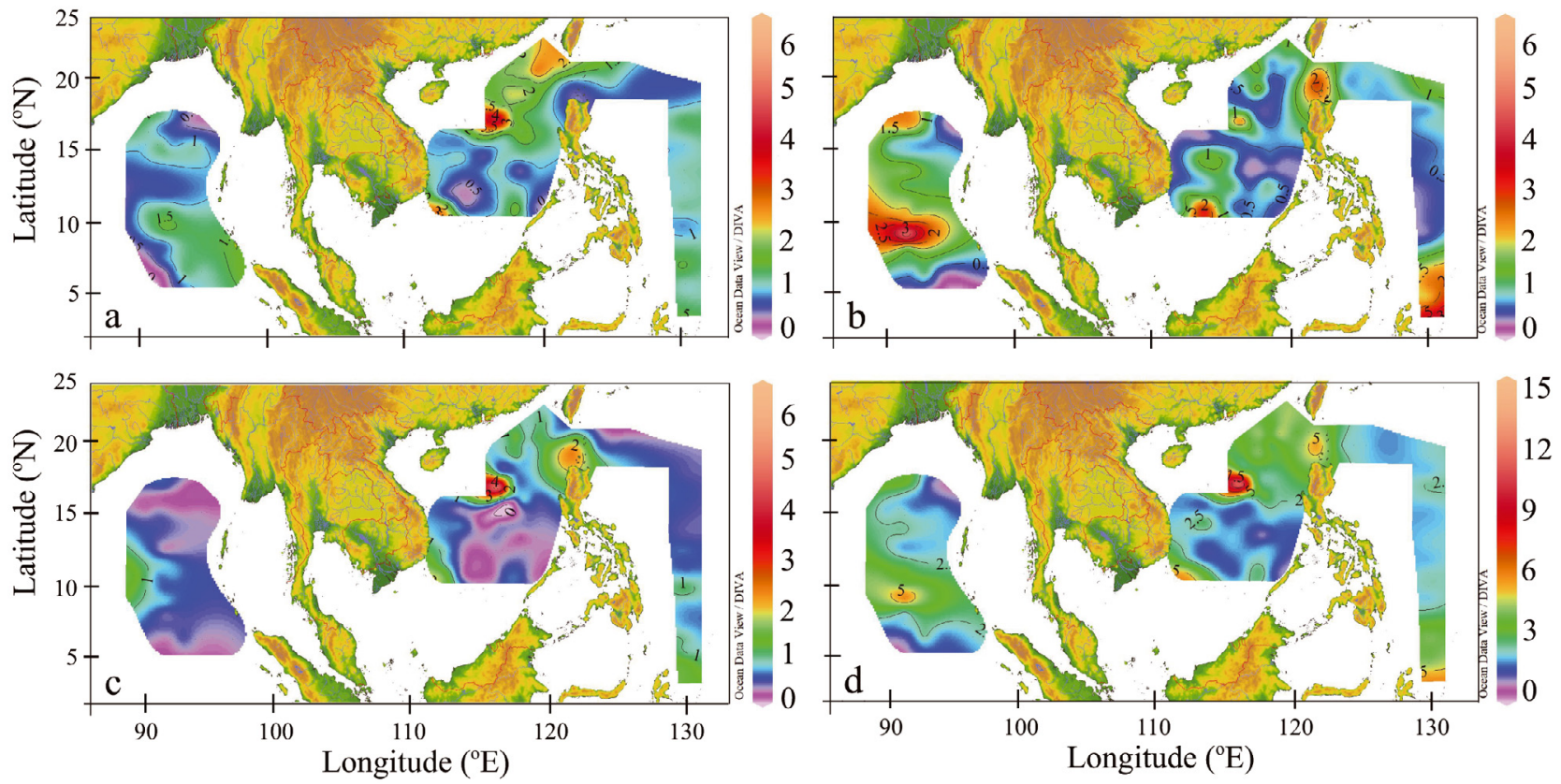

Fig. 6. Spatial distributions of depth-weighted average carbon biomass ( $\mu \mathrm{g} \mathrm{Cl}^{-1}$ ) of (a) Prochlorococcus (Pro), (b) Synechococcus (Syn), (c) picoeukaryotes (PEuks) and (d) total picophytoplankton in 3 contrasting seas. Note the different scale on the color bar in panel (d)

averaging ordination, particularly relating the biological assemblages of species to known environmental factors (ter Braak \& Verdonschot 1995). Moreover, CCA is an efficient indirect gradient analysis when species have regression response curves with respect to environmental gradients (Hill 1991). Questions in the relationship between species and environmental variables can be answered more directly by the CCA ordination. Within our study, the species-environment correlations of CCA axes 1 and 2 were 0.632 and 0.873 , respectively. The correlation coefficients among environmental axes were 0 , while the species axes were approximately vertical to each other. The $\mathrm{p}$-value for the significance test of all

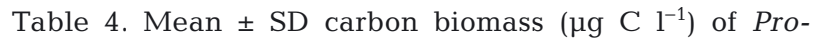
chlorococcus (Pro), Synechococcus (Syn) and picoeukaryotes (PEuks) along with respective relative biomass (\%; fraction of total picophytoplankton biomass) in 3 contrasting seas

\begin{tabular}{|lcccc|}
\hline \multirow{2}{*}{ Cell type } & & $\begin{array}{c}\text { West Pacific } \\
\text { Ocean }\end{array}$ & $\begin{array}{c}\text { South China } \\
\text { Sea }\end{array}$ & $\begin{array}{c}\text { Bay of } \\
\text { Bengal }\end{array}$ \\
\hline Pro & Mean & $1.13 \pm 0.22$ & $1.48 \pm 0.79$ & $1.05 \pm 0.34$ \\
& Percentage & 38 & 49 & 40 \\
Syn & Mean & $0.93 \pm 0.39$ & $0.81 \pm 0.35$ & $1.14 \pm 0.56$ \\
& Percentage & 32 & 27 & 43 \\
PEuks & Mean & $0.89 \pm 0.37$ & $0.72 \pm 0.46$ & $0.45 \pm 0.29$ \\
& Percentage & 30 & 24 & 17 \\
Total & & 2.95 & 3.01 & 2.64 \\
& & & & \\
\hline
\end{tabular}

canonical axes was 0.002 . Taken together, the relationships between Pro, Syn and PEuks and environmental variables (temperature, salinity, DIN, DIP and DSi) can be explained by the CCA ordination diagram (Fig. 7).

In the CCA ordination diagram, 3 picophytoplankton groups were positively correlated with water temperature (Pearson's correlation, $r>0.323, \mathrm{p}<0.01$; Table 5), indicating that temperature was an important factor in regulating the biogeographic variations of picophytoplankton. A negative correlation was observed between salinity and Syn $(r=-0.272, \mathrm{p}<0.01)$ and PEuks $(\mathrm{r}=-0.076, \mathrm{p}<0.05)$, indicating their coastal distributions especially in the SCS (Fig. 4). However, there was no significant correlation between salinity and Pro abundance $(r=0.031, p>0.05)$, thus indicating that the variation in salinity seemed to have little control over the abundance of total picophytoplankton due to the absolute dominance of Pro abundance (Table 3, Fig. 4). The 3 picophytoplankton groups showed a negative correlation with nutrients $(\mathrm{r}<-0.261, \mathrm{p}<0.01)$, indicating that the abundances of Pro, Syn and PEuks declined with the increase in nutrient concentrations and were thus found to have a maximum in oligotrophic waters (Fig. 4). This result also indicated that picophytoplankton growth was not constrained by low nutrient levels. Consequently, water temperature and nutrient availability were important factors explain- 
ing the biogeographic variations of picophytoplankton, whereas salinity explained relatively little.

\section{DISCUSSION}

\subsection{Abundance, spatial distribution and associated environmental variables}

Our dataset differs from previous efforts in having a wider biogeographic and environmental representation. Although Ribeiro et al. (2016) suggested that the low concentrations of photosynthetic pigments in Pro cells in surface waters may lead to an underestimation of abundance by the BD Accuri FCM, the average Pro abundances observed in the 3 contrasting seas are of the same magnitude as previous studies in other marine ecosystems (e.g. Flombaum et al. 2013, van den Engh et al. 2017, Wei et al. 2019a, Zhao et al. 2019). In addition, Pro cells in deeper waters containing relatively higher concentrations of pigments have allowed better detection on the BD Accuri FCM (Ribeiro et al. 2016); thus, this underestimation does not affect the spatial distribution patterns of abundance and biomass for Pro demonstrated herein (Bergo et al. 2017). Given the high sensitivity of our BD Accuri FCM after a series of instrument settings, however, we speculate that the potential disappearance of Pro at those depths is rather a reflection of the already low abundances found in shallower depths compared with other studies than a problem with the detection limit. To date,

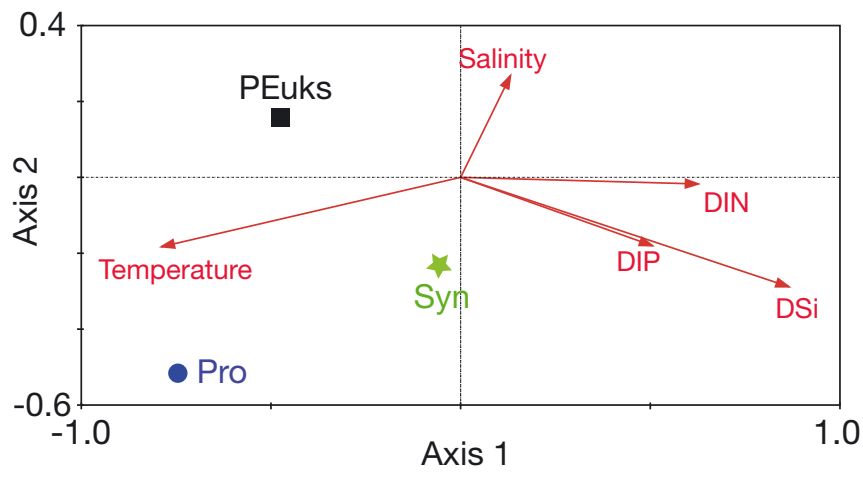

Fig. 7. Canonical correspondence analysis (CCA) plot for the relationship between picophytoplankton abundance and environmental variables across 3 contrasting seas $(n=882)$. The colored symbols correspond to 3 picophytoplankton groups (i.e. Pro: Prochlorococcus; Syn: Synechococcus; PEuks: picoeukaryotes). The vectors show the direction and strength of the environmental variables relative to the overall distribution. Picophytoplankton abundances were log transformed prior to analysis. DIN: dissolved inorganic nitrogen; DIP: dissolved inorganic phosphorus; DSi: dissolved inorganic silicate the BD Accuri FCM remains a major instrument for marine picophytoplankton research. For instance, Bergo et al. (2017) examined the spatial dynamics of abundance and biomass partitioning of Pro, Syn and PEuks across environmental gradients using a BD Accuri FCM; both Brandini et al. (2019) and Zhao et al. (2019) detected the Pro, Syn and PEuks abundances on the BD Accuri FCM to resolve the functional relationships between picophytoplankton abundances and oceanic properties.

The average abundances of total picophytoplankton observed for BOB, SCS and WPO within our study are comparable with other estimates (Table 3). For example, our estimated abundance of total picophytoplankton for the WPO $\left(2.5 \times 10^{4}\right.$ cells $\left.\mathrm{ml}^{-1}\right)$ was in good agreement with previously reported abundance of (2.0-3.8) $\times 10^{4}$ cells ml ${ }^{-1}$ (Landry et al. 2003, Cheung et al. 2008); Madhupratap et al. (2003) and Cai et al. (2007) estimated the total picophytoplankton abundances of $(0.2-18.5) \times 10^{4}$ and $5.1 \times 10^{4}$ cells $\mathrm{ml}^{-1}$, respectively, for the BOB and SCS, which were also close to our estimates of $4.7 \times 10^{4}$ cells $\mathrm{ml}^{-1}$. However, the estimated average abundances of Pro, Syn and PEuks in the 3 contrasting seas showed some differences with the average abundances reported by Agusti et al. (2019) (Table 6). The average Syn abundance in the WPO $\left(4.2 \times 10^{3} \mathrm{cells} \mathrm{ml}^{-1}\right)$

Table 5. Pearson's rank correlation coefficients between environmental factors and abundances of 3 picophytoplankton groups $(\mathrm{n}=882)$. Picophytoplankton abundances were log transformed prior to analysis. Syn: Synechococcus; Pro: Prochlorococcus; PEuks: picoeukaryotes; DIN: dissolved inorganic nitrogen; DIP: dissolved inorganic phosphorus; DSi: dissolved inorganic silicate. ${ }^{*} p<0.05\left(2\right.$-tailed) ${ }_{i}{ }^{* *} p<0.01$ (2-tailed)

\begin{tabular}{|lccccc|}
\hline & Temperature & Salinity & DIN & DIP & DSi \\
\hline Syn & $0.640^{* *}$ & $-0.272^{* *}$ & $-0.475^{* *}$ & $-0.339^{* *}$ & $-0.595^{* *}$ \\
Pro & $0.323^{* *}$ & 0.031 & $-0.316^{* *}$ & $-0.261^{* *}$ & $-0.467^{* *}$ \\
PEuks & $0.535^{* *}$ & $-0.076^{*}$ & $-0.463^{* *}$ & $-0.374^{* *}$ & $-0.647^{* *}$ \\
\hline
\end{tabular}

Table 6. Mean \pm SD abundances of 3 picophytoplankton populations (Syn: Synechococcus; Pro: Prochlorococcus; PEuks: picoeukaryotes) in each ocean basin and globally (Agusti et al. 2019)

\begin{tabular}{|c|c|c|c|}
\hline & $\begin{array}{c}\text { Pro } \\
\left(10^{4} \text { cells ml }{ }^{-1}\right)\end{array}$ & $\begin{array}{c}\text { Syn } \\
\left(10^{3} \text { cells } \mathrm{ml}^{-1}\right)\end{array}$ & $\begin{array}{c}\text { PEuks } \\
10^{3} \text { cells ml }^{-1} \text { ) }\end{array}$ \\
\hline Atlantic Ocean & $17.2 \pm 0.8$ & $4.9 \pm 0.4$ & $1.5 \pm 0.1$ \\
\hline Indian Ocean & $9.6 \pm 0.6$ & $8.1 \pm 1.5$ & $1.3 \pm 0.1$ \\
\hline Pacific Ocean & $8.3 \pm 0.3$ & $11.4 \pm 2.4$ & $2.1 \pm 0.3$ \\
\hline Global scale & $12.6 \pm 0.4$ & $7.7 \pm 0.8$ & $1.7 \pm 0.1$ \\
\hline
\end{tabular}


was 2 - to 3 -fold less than that $\left(11.2 \times 10^{3}\right.$ cells ml $\left.^{-1}\right)$ observed by Agusti et al. (2019) in the Pacific Ocean, whereas the average Syn abundance in the BOB $\left(10.1 \times 10^{3}\right.$ cells ml $\left.{ }^{-1}\right)$ was slightly higher than that in the Indian Ocean $\left(8.1 \times 10^{3}\right.$ cells ml $\left.{ }^{-1}\right)$. The average Pro and PEuks abundances in the BOB and WPO also differed from those in the Indian Ocean and Pacific Ocean, respectively.

Syn and PEuks are able to tolerate low temperature and are most abundant in coastal regions of the SCS with intermediate nutrient concentrations (Zubkov et al. 2000, Liu et al. 2007, Zhang et al. 2013). In the present study, Syn and PEuks abundances were inversely associated with salinity (Fig. 7). It is likely that salinity is a function of the freshwater input, which directly determines the high abundances of Syn and PEuks in coastal regions (Olson et al. 1990, Lee et al. 2014). As such, Syn and PEuks abundances were higher near the freshwater-dominated areas of the SCS (Fig. 4), which is likely due to the mesotrophic dilution waters (Zhang et al. 2013, Zhao et al. 2019).

Pro were the most abundant picophytoplankton group in the 3 contrasting seas (Table 3). Because of the predominance of Pro, the maximum carbon biomass of total picophytoplankton also occurred in the CSCS (Fig. 6), thus indicating the ecological importance of Pro as a primary producer. Pro were present in high abundances at low nutrient concentrations (Fig. 4), consistent with adaptation to growth under low nutrient availability (Olson et al. 1990, Zubkov et al. 2000, van den Engh et al. 2017, Wei et al. 2019b). It is usually believed that elevated nutrient concentrations and heavy metals induced by coastal currents or upwellings could be toxic to Pro growth (Mann et al. 2002, Gaulke et al. 2010, Lee et al. 2014). As a result of these toxic effects, Pro abundance was usually high in the oligotrophic open waters (Fig. 4). Water temperature was also one of the key factors limiting the coastal distribution of Pro (Fig. 7); however, this response to water temperature is consistent with previous reports (Moore et al. 1995, Zinser et al. 2007, Agusti et al. 2019). For example, Pro growth is generally limited below water temperatures of $15-$ $18^{\circ} \mathrm{C}$ and inhibited at water temperatures above $25^{\circ} \mathrm{C}$ (Moore et al. 1995, Buck et al. 1996). Interestingly, Pro were exceptionally abundant along the NSCS coast other than in the CSCS (Fig. 4). The hydrographic conditions near the NSCS coast, characterized by high temperature and salinity, were apparently affected by the Kuroshio intrusion (Fig. 2). We therefore confirmed that the exceptional presence of Pro near the coast of the SCS was potentially associated with the Kuroshio intrusion. Analogous studies have shown that the effect of the Kuroshio intrusion potentially resulted in the exceptional presence of Pro near the coast (Chen et al. 2011, Lee et al. 2014). Collectively, Pro are most abundant in the oligotrophic open waters, but they are by no means restricted to this habitat. In addition, light, water turbidity and disturbance, competition among groups, ecotype succession and grazing pressure are all important controlling factors (Landry et al. 2003, Grébert et al. 2018, Wei et al. 2019a). The partial increase in nutrient availability particularly in the oligotrophic open oceans can also stimulate the Pro growth (discussed below), indicating that some undiscovered factors may also influence the biogeographic variations of picophytoplankton at the global scale. However, our research is not fine-scaled enough to resolve the close associations between physiological features and biogeographic distributions of picophytoplankton; more data are needed.

\subsection{Physical processes in regulating the biogeographic variation of picophytoplankton}

Three picophytoplankton populations showed negative correlations with nutrient concentrations (Fig. 7, Table 5), thus high nutrient concentrations seem to restrict their coastal distributions. The same conclusion was reached by Gaeta et al. (1999) and Brandini et al. (2019), who also find a negative correlation between the dynamics of picophytoplankton abundance and nutrient concentrations. However, comparison with other observations indicates that nutrient availability may be a major factor responsible for the coastal distributions of picophytoplankton, especially for the Syn and PEuks (Jiao et al. 2005, Liu et al. 2007, Zhang et al. 2013, Zhao et al. 2019). On the other hand, the maximal abundances of 3 picophytoplankton groups in vertical distribution showed strong positive correlations with the nutricline depth (Figs. $3 \& 5$ ). Therefore, nutrient availability has a 2 -faceted role in regulating the spatial patterns of picophytoplankton in different marine ecosystems. Light irradiance is a key limiting factor for the temporal-spatial distributions of picophytoplankton (Flombaum et al. 2013, Agusti et al. 2019). Recent studies suggested that Pro are more sensitive to sunlight, particularly to UV (Llabrés \& Agustí 2006), but this does not occur for Syn. Accordingly, Pro are better adapted to capture the blue wavelengths that predominate deeper in the water column (Moore et al. 1995, Dusenberry et al. 2000, Grébert et al. 2018). Due to the apparent stratification in the tropical and subtropical oligotrophic gyres, 
nutrients were almost depleted within the euphotic zone, whereas nutrient supply was sufficient in the deeper layer (Fig. 3). Picophytoplankton abundance was not higher under conditions with high nutrients below the euphotic layer, which may be reasonably driven by light limitation. Therefore, light availability may help explain this 2-faceted role of nutrients in regulating the biogeographic variation in picophytoplankton. Several investigations have revealed that 2 ecotypes of Pro can be adapted to grow at different light intensities (e.g. Zinser et al. 2007), but we did not observe the co-occurrence of different Pro on our BD Accuri FCM analysis.

In the absence of physical input of new nutrients, particularly for oligotrophic waters, nutrient availability is significant for the picophytoplankton growth. Previous research on physical processes has indicated that Pro, Syn and PEuks alternatively dominate in different water masses or circulations, because their hydrographic properties such as temperature, salinity and nutrients can be important controlling factors for picophytoplankton distributions (Agustí 2004, Flombaum et al. 2013). For example, the exceptional presence of Pro near the SCS coast may be potentially caused by the effect of the Kuroshio intrusion (Jiao \& Yang 2002, Chen et al. 2011, Lee et al. 2014); high Syn and PEuks abundances are observed in areas dominated by coastal currents or upwelling regions (Chen et al. 2011). In particular, picophytoplankton within an eddy have different biogeographic characteristics than outside the eddy (Chen et al. 2015). Processmodel studies indicated that both vertical and lateral nutrient supplies by mesoscale eddies are considerably effective for picophytoplankton growth near the margins of the oligotrophic gyre (Oschlies 2002). Eddy-related nutrient injections within the euphotic zone, especially cold eddies, can significantly enhance biological production in the oligotrophic waters (McGillicuddy \& Robinson 1997, Vaillancourt et al. 2003). Šantić et al. (2011) also highlighted that the abundance of Pro can be influenced by nutrient availability, but as a consequence of the movement of cold eddies. The sea level anomaly and the hydrographic conditions at $10^{\circ} \mathrm{N}$ in the BOB were consistent with the presence of a cold eddy (Figs. $2 \& 3$ ). Thus, Pro abundance was relatively high around the $10^{\circ} \mathrm{N}$ in the $\mathrm{BOB}$ (Fig. 4) because of the relatively high nutrient concentrations supplied by the cold eddy. Overall, cold eddies play an important role in influencing biogeographic distributions of picophytoplankton because of eddy-induced upward nutrient pumping. Inversely, the biogeographic variations in picophytoplankton may be an indicator for water masses or circulations.

\subsection{Size-derived conversion factors and carbon biomass}

There is significant uncertainty over carbon biomass of picophytoplankton, stemming from the uncertainties in both cell size and abundance-to-carbon conversion factors. Within the present study, we used a conversion factor of $964 \mathrm{fg} \mathrm{C} \mathrm{cell}^{-1}$ for PEuks in the WPO (Table 1). However, this conversion factor may provide a lower estimation of carbon biomass for PEuks than previous biomass values in the WPO. Liu et al. (2007) also indicated that the estimated PEuks cell size $(1.31 \pm 0.30 \mu \mathrm{m})$ in the SCS is somewhat smaller than other estimates, thus resulting in a low conversion factor (293 fg C cell ${ }^{-1}$; Table 1). Overall, the main reason that our estimates of carbon biomass of PEuks may be on the low end of all the estimates is that we have adopted newly derived conversion factors; however, we believe it is a more accurate carbon density factor than most previously used values.

Although the carbon biomass was much higher in the SCS and WPO than in the BOB, it is essential to emphasize that these calculated carbon biomasses are not applied to compare the biogeographic variation, which is principally due to great plasticity in the conversion factor under different taxonomic and ambient conditions. Meanwhile, it is not meaningful to directly compare our biomass estimates with previous reports, since different carbon conversion factors were used in different studies.

Acknowledgements. This research was partly supported by the National Key Research and Development Program of China (2019YFC1407805), and also financially supported by National Nature Science Foundation of China programs (41876134, 41676112 and 41276124), the University Innovation Team Training Program for Tianjin (TD12-5003), the Tianjin 131 Innovation Team Program (20180314) and the Changjiang Scholar Program of the Chinese Ministry of Education (T2014253) to J.S. We also thank the Open Cruise Project in the Western Pacific Ocean of the National Nature Science Foundation of China (NORC2016-08) for sharing their ship time.

\section{LITERATURE CITED}

Agustí S (2004) Viability and niche segregation of Prochlorococcus and Synechococcus cells across the Central Atlantic Ocean. Aquat Microb Ecol 36:53-59

Agusti S, Lubián LM, Moreno-Ostos E, Estrada M, Duarte CM (2019) Projected changes in photosynthetic picoplankton in a warmer subtropical ocean. Front Mar Sci 5: 506

Bergo NM, Signori CN, Amado AM, Brandini FP, Pellizari VH (2017) The partitioning of carbon biomass among the pico-and nano-plankton community in the South Brazilian Bight during a strong summer intrusion of South Atlantic central water. Front Mar Sci 4:238 
Bertilsson S, Berglund O, Karl DM, Chisholm SW (2003) Elemental composition of marine Prochlorococcus and Synechococcus: implications for the ecological stoichiometry of the sea. Limnol Oceanogr 48:1721-1731

Brandini FP, Sayeg L, Ruske G, Campos G, Chuqui M, Jovane L (2019) Carbon flow for plankton metabolism of Saco do Mamanguá Ría, Bay of Ilha Grande, a subtropical coastal environment in the South Brazil Bight. Front Mar Sci 6:584

Brzezinski MA, Nelson DM (1986) A solvent extraction method for the colorimetric determination of nanomolar concentrations of silicic acid in seawater. Mar Chem 19: 139-151

Buck KR, Chavez FP, Campbell L (1996) Basin-wide distributions of living carbon components and the inverted trophic pyramid of the central gyre of the North Atlantic Ocean, summer 1993. Aquat Microb Ecol 10:283-298

* Cai YM, Ning XR, Liu CG, Hao Q (2007) Distribution pattern of photosynthetic picoplankton and heterotrophic bacteria in the northern South China Sea. J Integr Plant Biol 49:282-298

* Calvo-Díaz A, Morán XAG (2006) Seasonal dynamics of picoplankton in shelf waters of the southern Bay of Biscay. Aquat Microb Ecol 42:159-174

Campbell L, Liu H, Nolla HA, Vaulot D (1997) Annual variability of phytoplankton and bacteria in the subtropical North Pacific Ocean at Station ALOHA during the 1991-1994 ENSO event. Deep Sea Res I 44:167-192

Chen B, Wang L, Song S, Huang B, Sun J, Liu H (2011) Comparisons of picophytoplankton abundance, size, and fluorescence between summer and winter in northern South China Sea. Cont Shelf Res 31:1527-1540

* Chen YLL, Chen HY, Jan S, Lin YH, Kuo TH, Hung JJ (2015) Biologically active warm-core anticyclonic eddies in the marginal seas of the western Pacific Ocean. Deep Sea Res I 106:68-84

* Cheung MK, Chu KH, Li CP, Kwan HS, Wong CK (2008) Genetic diversity of picoeukaryotes in a semi-enclosed harbour in the subtropical western Pacific Ocean. Aquat Microb Ecol 53:295-305

* Crosbie ND, Furnas MJ (2001) Abundance, distribution and flow-cytometric characterization of picophytoprokaryote populations in central $\left(17^{\circ} \mathrm{S}\right)$ and southern $\left(20^{\circ} \mathrm{S}\right)$ shelf waters of the Great Barrier Reef. J Plankton Res 23: 809-828

NDusenberry JA, Olson RJ, Chisholm SW (2000) Field observations of oceanic mixed layer dynamics and picophytoplankton photoacclimation. J Mar Syst 24:221-232

Flombaum P, Gallegos JL, Gordillo RA, Rincón J, Zabala LL, Jiao N, Vera CS (2013) Present and future global distributions of the marine Cyanobacteria Prochlorococcus and Synechococcus. Proc Natl Acad Sci USA 110: 9824-9829

Gaeta SA, Ribeiro SMS, Metzler PM, Francos MS, Abe DS (1999) Environmental forcing on phytoplankton biomass and primary productivity of the coastal ecosystem in Ubatuba region, southern Brazil. Rev Bras Oceanogr 47: $11-27$

Gaulke AK, Wetz MS, Paerl HW (2010) Picophytoplankton: a major contributor to planktonic biomass and primary production in a eutrophic, river-dominated estuary. Estuar Coast Shelf Sci 90:45-54

Grébert $T$, Doré $H$, Partensky F, Farrant GK, Boss ES, Picheral M, Acinas SG (2018) Light color acclimation is a key process in the global ocean distribution of Syne- chococcus cyanobacteria. Proc Natl Acad Sci USA 115: E2010-E2019

*Grob C, Hartmann M, Zubkov MV, Scanlan DJ (2011) Invariable biomass specific primary production of taxonomically discrete picoeukaryote groups across the Atlantic Ocean. Environ Microbiol 13:3266-3274

* Hill MO (1991) Patterns of species distribution in Britain elucidated by canonical correspondence analysis. J Biogeogr 18:247-255

Jiao N, Yang Y (2002) Ecological studies on Prochlorococcus in China seas. Chin Sci Bull 47:1243-1250

* Jiao N, Yang Y, Hong N, Ma Y, Harada S, Koshikawa H, Watanabe $M$ (2005) Dynamics of autotrophic picoplankton and heterotrophic bacteria in the East China Sea. Cont Shelf Res 25:1265-1279

*Karl DM, Tien G (1992) MAGIC: a sensitive and precise method for measuring dissolved phosphorus in aquatic environments. Limnol Oceanogr 37:105-116

* Landry MR, Brown SL, Neveux J, Dupouy C, Blanchot J, Christensen S, Bidigare RR (2003) Phytoplankton growth and microzooplankton grazing in high nutrient, low chlorophyll waters of the equatorial Pacific: community and taxon specific rate assessments from pigment and flow cytometric analyses. J Geophys Res 108:8142

Lee Y, Choi JK, Youn S, Roh S (2014) Influence of the physical forcing of different water masses on the spatial and temporal distributions of picophytoplankton in the northern East China Sea. Cont Shelf Res 88:216-227

พ Liu H, Chang J, Tseng CM, Wen LS, Liu KK (2007) Seasonal variability of picoplankton in the Northern South China Sea at the SEATS station. Deep Sea Res II 54:1602-1616

KLlabrés M, Agustí S (2006) Picophytoplankton cell death induced by UV radiation: evidence for oceanic Atlantic communities. Limnol Oceanogr 51:21-29

*Madhupratap M, Gauns M, Ramaiah N, Kumar SP, Muraleedharan PM, De Sousa SN, Muraleedharan U (2003) Biogeochemistry of the Bay of Bengal: physical, chemical and primary productivity characteristics of the central and western Bay of Bengal during summer monsoon 2001. Deep Sea Res II 50:881-896

* Mann EL, Ahlgren N, Moffett JW, Chisholm SW (2002) Copper toxicity and cyanobacteria ecology in the Sargasso Sea. Limnol Oceanogr 47:976-988

* McGillicuddy DJ Jr, Robinson AR (1997) Eddy-induced nutrient supply and new production in the Sargasso Sea. Deep Sea Res I 44:1427-1450

Menden-Deuer S, Lessard EJ (2000) Carbon to volume relationships for dinoflagellates, diatoms, and other protist plankton. Limnol Oceanogr 45:569-579

*Moore LR, Goericke R, Chisholm SW (1995) Comparative physiology of Synechococcus and Prochlorococcus: influence of light and temperature on growth, pigments, fluorescence and absorptive properties. Mar Ecol Prog Ser 116:259-275

* Olson RJ, Chisholm SW, Zettler ER, Altabet MA, Dusenberry JA (1990) Spatial and temporal distributions of prochlorophyte picoplankton in the North Atlantic Ocean. Deep Sea Res I 37:1033-1051

* Oschlies A (2002) Can eddies make ocean deserts bloom? Global Biogeochem Cycles 16:1106

Qu T, Du Y, Meyers G, Ishida A, Wang D (2005) Connecting the tropical Pacific with Indian Ocean through South China Sea. Geophys Res Lett 32:L24609

Quere CL, Harrison SP, Prentice IC, Buitenhuis ET, Aumont O, Bopp L, Klaas C (2005) Ecosystem dynamics based on 
plankton functional types for global ocean biogeochemistry models. Glob Change Biol 11:2016-2040

Ribeiro GC, Marie D, Lopes dos Santos A, Pereira Brandini F, Vaulot D (2016) Estimating microbial populations by flow cytometry: comparison between instruments. Limnol Oceanogr Methods 14:750-758

Šantić D, Krstulovi N, Šolić M, Kušpilić G (2011) Distribution of Synechococcus and Prochlorococcus in the central Adriatic Sea. Acta Adriat 52:101-114

Sengupta D, Ravichandran M (2001) Oscillations of Bay of Bengal sea surface temperature during the 1998 summer monsoon. Geophys Res Lett 28:2033-2036

Seymour JR, Ahmed T, Durham WM, Stocker R (2010) Chemotactic response of marine bacteria to the extracellular products of Synechococcus and Prochlorococcus. Aquat Microb Ecol 59:161-168

ter Braak CJF, Verdonschot PFM (1995) Canonical correspondence analysis and related multivariate methods in aquatic ecology. Aquat Sci 57:255-289

Vaillancourt RD, Marra J, Seki MP, Parsons ML, Bidigare RR (2003) Impact of a cyclonic eddy on phytoplankton community structure and photosynthetic competency in the subtropical North Pacific Ocean. Deep Sea Res I 50:829-847

Van den Engh GJ, Doggett JK, Thompson AW, Doblin MA, Gimpel CNG, Karl DM (2017) Dynamics of Prochlorococcus and Synechococcus at station ALOHA revealed

Editorial responsibility: Curtis Suttle, Vancouver, British Columbia, Canada through flow cytometry and high-resolution vertical sampling. Front Mar Sci 4:359

Wei Y, Sun J, Zhang X, Wang J, Huang K (2019a) Picophytoplankton size and biomass around equatorial eastern Indian Ocean. MicrobiologyOpen 8:e00629

*Wei Y, Zhang G, Chen J, Wang J, Ding C, Zhang X, Sun J (2019b) Dynamic responses of picophytoplankton to physicochemical variation in the eastern Indian Ocean. Ecol Evol 9:5003-5017

* Zhang X, Shi Z, Liu Q, Ye F, Tian L, Huang X (2013) Spatial and temporal variations of picoplankton in three contrasting periods in the Pearl River Estuary, South China. Cont Shelf Res 56:1-12

Z Zhao Y, Yu RC, Kong FZ, Wei CJ, Liu Z, Geng HX, Zhou MJ (2019) Distribution patterns of picosized and nanosized phytoplankton assemblages in the East China Sea and the Yellow Sea: implications on the impacts of Kuroshio Intrusion. J Geophys Res 124:1262-1276

* Zinser ER, Johnson ZI, Coe A, Karaca E, Veneziano D, Chisholm SW (2007) Influence of light and temperature on Prochlorococcus ecotype distributions in the Atlantic Ocean. Limnol Oceanogr 52:2205-2220

Kubkov MV, Sleigh MA, Burkill PH, Leakey RJ (2000) Picoplankton community structure on the Atlantic Meridional Transect: a comparison between seasons. Prog Oceanogr 45:369-386

Submitted: September 3, 2019; Accepted: February 5, 2020 Proofs received from author(s): April 4, 2020 